\title{
Blonanserin N-Oxide Lowers Glucose Levels in Animal Models
}

\author{
Maddileti $\mathrm{D}^{1}$, Mannava $\mathrm{C}^{1,2}$, Swapna $\mathrm{B}^{1}$, Tejpal $\mathrm{R}^{2}$, Konga $\mathrm{DB}^{3}$, Rao Khandavilli $\mathrm{UB}^{2}$, Kokkonda $\mathrm{V}^{2}$, \\ Medipelli $\mathrm{SR}^{2}$, Mummareddy $\mathrm{S}^{3}$, Ernest $\mathrm{K}^{4}$, Kona $\mathrm{K}^{4}$, Vangalapudi $\mathrm{L}^{4}$ and Nangia $\mathrm{A}^{\mathrm{t}_{1,2,4}}$ \\ ${ }^{1}$ School of Chemistry, University of Hyderabad, Prof. C. R. Rao Road, Gachibowli, Central University, Hyderabad, \\ India \\ ${ }^{2}$ Technology Business Incubator, University of Hyderabad, Prof. C. R. Rao Road, Gachibowli, Hyderabad, India \\ ${ }^{3}$ Virchow Biotech Pvt. Ltd., Animal House Facility, S. V. Co-op Industrial Estate, IDA Jeedimetla, Hyderabad, India \\ ${ }^{4}$ Life Science Incubator, IKP Knowledge Park, Genome Valley, Turkapally, Shameerpet, Hyderabad, India
}

*Corresponding author: Nangia A, Technology Business Incubator, Room No. 2 \& 5, University of Hyderabad, Prof. C. R. Rao Road, Gachibowli, Hyderabad 500 046, India, E-mail: ashwini.nangia@gmail.com

Citation: Maddileti D, Mannava C, Swapna B, Tejpal R, Konga DB, et al. (2017) Blonanserin N-Oxide Lowers Glucose Levels in Animal Models. J Pharm Drug Devel 4(1): 102. doi: 10.15744/2348-9782.4.102

Received Date: February 13, 2017 Accepted Date: May 27, 2017 Published Date: May 29, 2017

\begin{abstract}
The N-oxide of anti-psychotic drug Blonanserin (BLNO) was synthesized and tested as a novel molecule to understand its ability in reducing blood glucose levels. Administration of BLNO at $1 \mathrm{mg} / \mathrm{kg}$ ( $\mathrm{mpk}, \mathrm{mg}$ of drug per $\mathrm{kg}$ of rat body weight) to diabetic Wistar rats (induced by treatment of $40 \mathrm{mg} / \mathrm{kg}$ streptozotocin, STZ) showed reduced glucose levels at $100 \mathrm{mg} / \mathrm{dL}$ in a 28 day study, compared to the control group (with no drug added only STZ induced) which reached hyperglycemic levels of 500-600 mg/dL. At $5 \mathrm{mpk}$ of BLNO, glucose levels were controlled in a 18 day study and no toxic or adverse indications were observed at the higher $5 \mathrm{X}$ dose. Oral glucose tolerance test on Wistar rats confirmed the potential of BLNO to reduce glucose levels at 5 mpk dose, comparable to that of marketed drugs metformin HCl (MHCL) and sitagliptin phosphate monohydrate (SPMH) at $100 \mathrm{mpk}$ dose in 90-120 min after drug administration. A novel molecule Blonanserin- $\mathrm{N}$-oxide is identified as a potential anti-diabetic drug lead for controlling blood glucose levels.
\end{abstract}

Keywords: Diabetes; Glucose; Blonanserin; N-Oxide; GPCR; Antipsychotic

\section{Introduction}

Type-2 Diabetes mellitus (DM) is a metabolic disorder caused by insulin resistance (dysfunction of pancreatic beta cells) and obesity. It is now recognized as a major health problem worldwide and affects adults of working age in developing countries. WHO estimates on the global prevalence of diabetes are expected to increase from 171 million in 2000 to 366 million in 2030 . As a matter of fact $21.7 \%$ of these ( $~ 80$ million) will be from India [1]. A first-line treatment for diabetes is lifestyle changes such as low calorie diet, weight control, and regular physical activity. If blood sugar (glucose) levels still remain high, then the patient is administered anti-diabetic drugs (for Type-2 diabetes) or insulin (Type-1 diabetes mellitus). A major challenge in T2DM therapy is how to make the pancreas more insulin sensitive. The other goal is to increase endogenous insulin levels in T2DM patients. One way to address the problem is to target pancreatic $\beta$-cells for increasing endogenous insulin levels via small molecule drugs (bigunides, sulfonylureas, meglitinides, thiazolidinediones, alpha-glucosidase inhibitors, dipeptidyl-peptidase IV inhibitors, incretin-based therapies, etc.) [2-4]. Metformin (bigunide), is the classic example of a T2DM drug which is an insulin sensitizer. However metformin requires circulating insulin levels for drug action but does not activate insulin secretion. The sulfonylureas, or ATP channel blockers, gliclazide, glimepiride, glipizide, tolbutamide, etc. promote the release of insulin from the $\beta$-cells by blocking the ATP-sensitive $\mathrm{K}^{+}$-channels, thereby resulting in depolarization with $\mathrm{Ca}^{+2}$-influx which activates insulin secretion. However, a serious side-effect of the sulfonyl urea drugs is hypoglycaemia, which happens due to excess insulin release. This means that the patient has to have additional sugar or carbohydrate to normalize insulin levels. The dipeptidyl peptidase IV inhibitors (also known as incretin enhancers or DPP-IV inhibitors, [5] are the latest generation T2DM drug molecules, e.g. sitagliptin, linagliptin, saxagliptin, and vildagliptin [6]. The glucagon like peptide (GLP-1 and 2) are natural incretin hormones which are released from the gut in response to food intake, and they are collectively responsible for glucose-dependent insulin release [7]. The physiological activity of the incretin hormones is limited by DPP-IV peptidase enzyme which cleaves the terminal end of active GLP to inactive 
peptide. This is reversed by the gliptin drugs, which are tight binding inhibitors of the DPP-IV enzyme. An advantage of the gliptins, compared to say the glitazones, is that since GLP levels are modulated by food intake, insulin release occurs post prandial and hence hypoglycemic condition is avoided. However, complete studies on the potential side effects of incretin-based gliptins are still ongoing [8].

There is increasing evidence in the past decade that patients taking anti-psychotic drugs for schizophrenia run an increased risk of diabetes mellitus [9]. That anti-psychotic drugs cause weight gain, and together with reduced physical activity in such patients, are additional factors for the high incidences of T2DM in psychotic patients $[10,11]$. A recent study showed that phosphorylation of M3-muscarinic receptor plays an important mechanistic role in facilitating insulin release from pancreatic islets by coupling of the receptor to protein kinase D1 [12]. These muscarinic acetylcholine receptors are a subfamily of GPCRs recognizing the neurotransmitter acetylcholine and signaling through $\mathrm{G}$ proteins of the $\mathrm{Gq} / 11$ class. These receptors are also targets for the treatment of diabetes and have been implicated in the treatment of cognitive disorders such as Alzheimer's disease and schizophrenia.

The N-oxide of anti-psychotic drug clozapine (CLNO, clozapine $\mathrm{N}$-oxide) is a natural metabolite and it was studied in transgenic mice for the activation of $\beta$-cell signaling pathway in vivo [13]. When transgenic (Tg) mice were injected with glucose alone, the blood glucose and insulin levels remained similar to the wild type set. However, co-injection of glucose (3 g/kg, i.p.) with CLNO $(1 \mathrm{mg} / \mathrm{kg}$ i.p. $)$ resulted in an immediate increase in insulin release $(2 \mathrm{~min})$ and subsequent time points (up to $15 \mathrm{~min})$, at levels almost 12 times higher than the first $10 \mathrm{~min}$, compared to the control group. There was a two-fold increase in islet density and $30 \%$ increase in $\beta$-cell mass size after a 2 weeks treatment [14]. Thus the pharmacological effects of CLNO are fundamentally different compared to previous drug classes, in that it not only activates insulin secretion instantaneously but also increases the size and mass of the pancreatic islet $\beta$-cells [15]. In the same class of anti-psychotic drugs is blonanserin (BLN), an agent with dopamine D2 and serotonin 5-HT2A receptor antagonist properties, [15] similar to SNRI drug clozapine (CLN) (serotonin norepinephrine reuptake inhibitors); both drugs are used in the treatment of schizophrenia and central nervous system (CNS) disorders [16]. Based on the structural similarity of these two molecules (Figure 1), we undertook the synthesis of the natural metobolite BLNO and to screen its anti-diabetic activity.

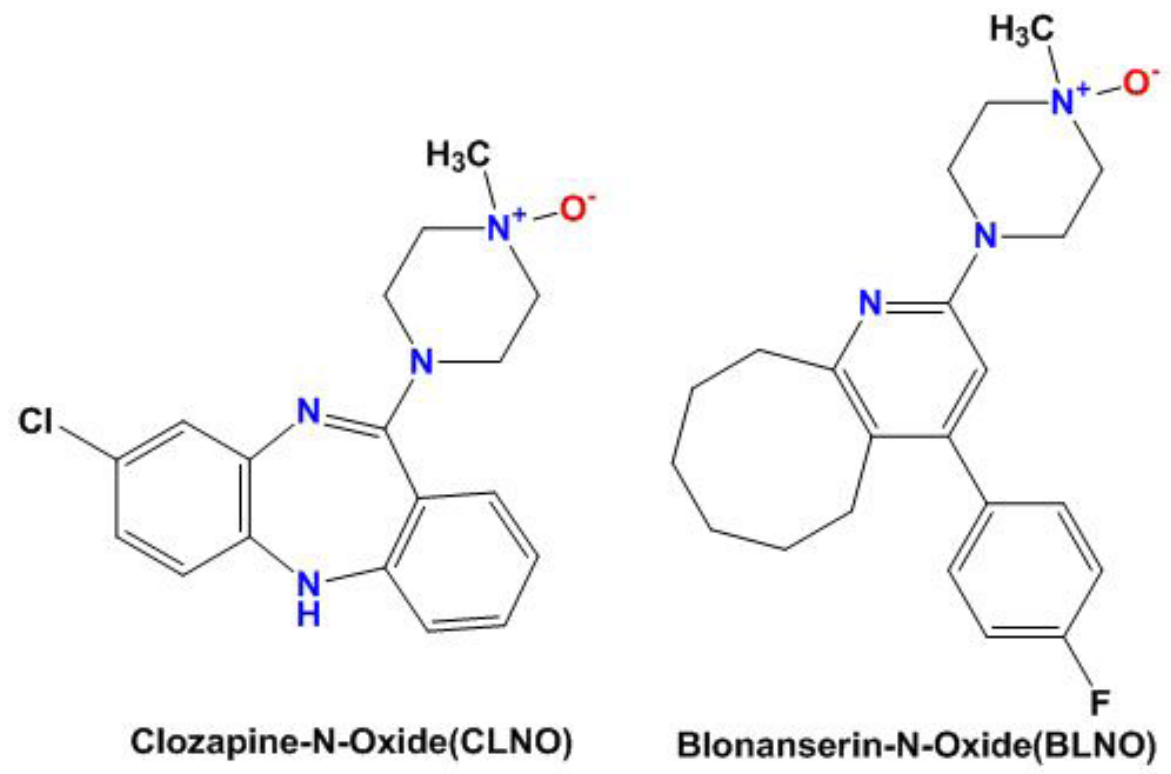

Figure 1: Chemical diagram of CLNO and BLNO discussed in this paper. The structures without the $\mathrm{N}$-oxide group are anti-psychotic drugs on the market, clozapine and blonanserin.

\section{Materials and Methods}

Blonanserin was purchased from Mesochem Technology Co. Ltd., China, and used without further purification. Clozapine was purchased from Shanghai Xunxin Chemical Co Ltd, China. All other chemicals and reagents were purchased from domestic suppliers and are of analytical grade purity. Metformin hydrochloride (MHCL) and Sitagliptin phosphate monohydrate (SPMH) were purchased from drugs suppliers. Streptozotocin and solvents and reagents were purchased from Sigma-Aldrich and Merck (Hyderabad, India).

\section{Synthesis of Blonanserin N-oxide (BLNO)}

Blonanserin (200 mg, $0.54 \mathrm{mmol}$ ) was dissolved in $15 \mathrm{~mL}$ of methanol and stirred at room temperature until it dissolved completely. To this reaction mixture $1.44 \mathrm{~mL}$ of $30 \% \mathrm{H}_{2} \mathrm{O}_{2}$ was added and refluxed at $70{ }^{\circ} \mathrm{C}$ for $2 \mathrm{~h}$. After completion of the reaction (by TLC), methanol was removed by rotary evaporator resulting in a viscous liquid. The reaction mixture was diluted with water and extracted with $\mathrm{CHCl}_{3}$. Drying of the organic layer with $\mathrm{Na}_{2} \mathrm{SO}_{4}$ evaporation of volatiles and drying on a vacuum pump for $2 \mathrm{~h}$ afforded a 
white solid which was purified by recrystallization from n-pentane. Yield $150 \mathrm{mg}$ (70\%); m.p. 153-155 ${ }^{\circ} \mathrm{C}$ (decomposition) [17]. $30 \mathrm{mg}$ of this BLNO was dissolved in $5 \mathrm{~mL}$ DMSO: $\mathrm{H}_{2} \mathrm{O}(1: 1 \mathrm{v} / \mathrm{v})$ and left for slow evaporation at room temperature. Good quality single crystals were harvested after about one week for single crystal X-ray diffraction analysis.

${ }^{1} \mathrm{H} \mathrm{NMR}\left(\mathrm{CDCl}_{3}, 400 \mathrm{MHz}\right): 7.22(\mathrm{t}, \mathrm{J} 12 \mathrm{~Hz}, 2 \mathrm{H}), 7.10$ (t, $\left.12 \mathrm{~Hz}, 2 \mathrm{H}\right), 6.37$ (s, $\left.1 \mathrm{H}\right), 4.13(\mathrm{~d}, 11 \mathrm{~Hz}, 2 \mathrm{H}), 3.82(\mathrm{t}, 8 \mathrm{~Hz}, 2 \mathrm{H}), 3.50-$ $3.35(\mathrm{~m}, 2 \mathrm{H}), 3.35-3.20(\mathrm{~m}, 2 \mathrm{H}), 2.90(\mathrm{~d}, 4 \mathrm{~Hz}, 2 \mathrm{H}), 2.60(\mathrm{t}, 8 \mathrm{~Hz}, 2 \mathrm{H}), 1.80(\mathrm{~m}, 3 \mathrm{H}), 1.50-1.36(\mathrm{~m}, 10 \mathrm{H})$.

IR (KBr, cm $\left.{ }^{-1}\right):$ 3412(br.), 2928, 2853, 1588, 1542, 1502, 1458, 1413, 1222, 1155, 1093

HRMS: m/z $384[M+1]$ peak

\section{X-ray crystallography}

X-ray reflections were collected on Oxford CCD X-ray diffractometer (Yarnton, Oxford, UK) equipped with Mo-Ka radiation ( $\lambda$ $=0.71073 \AA)$ and $\mathrm{Cu}-\mathrm{Ka} \mathrm{X}$-radiation $(\lambda=1.5406 \AA)$ source. Data reduction was performed using CrysAlisPro 171.33 .55 software. Crystal structures were solved and refined using Olex 2-1.0 with anisotropic displacement parameters for non- $\mathrm{H}$ atoms. Hydrogen atoms were experimentally located through the Fourier difference electron density maps in all crystal structures. All O-H and $\mathrm{C}-\mathrm{H}$ atoms were geometrically fixed using HFIX command in SHELX-TL program of Bruker-AXS. X-Seed was used to prepare packing diagrams.

\section{Crystallographic parameters of BLN-O dihydrate}

Empirical formula: $\mathrm{C}_{23} \mathrm{H}_{34} \mathrm{FN}_{3} \mathrm{O}_{3}$, Formula weight: 473.5, Crystal system: Orthorhombic, Space group: $P b c a, T=298 \mathrm{~K}, \mathrm{a}=$ 8.8000(7); $b=13.9995(15) ; c=36.033(3) \AA, a=\beta=\gamma=90^{\circ}, Z=8, Z^{\prime}=1, V=4439.1(7) \AA^{3}$, $R$-factor $=0.0734$ [18].

\section{Synthesis of Clozapine N-oxide (CLNO)}

Clozapine (200 mg, $0.61 \mathrm{mmol}$ ) was dissolved in $4 \mathrm{~mL}$ of dichloromethane and kept at $0{ }^{\circ} \mathrm{C}$ for 5 min. To the cooled solution, m-CPBA ( $180 \mathrm{mg}, 1.15 \mathrm{mmol})$ as a solution in $\mathrm{CH}_{2} \mathrm{Cl}_{2}$ was added drop wise at $0{ }^{\circ} \mathrm{C}$. After $1 \mathrm{~h}$, TLC indicated that the reaction was complete. $\mathrm{NaHCO}_{3}$ solution was added and stirred for $10 \mathrm{~min}$. The reaction mixture was extracted with $\mathrm{CHCl}_{3}$ and the organic layer was dried with $\mathrm{Na}_{2} \mathrm{SO}_{4}$. Evaporation of the solvent afforded a light yellow solid which under vacuum for $2 \mathrm{~h}$. Purification by recrystallizaton from $\mathrm{n}$-hexane afforded CLNO. Yield: $160 \mathrm{mg}(80 \%)$, m.p. 190-200 ${ }^{\circ} \mathrm{C}$ (dec.). Clozapine N-oxide was also oxidized using $30 \% \mathrm{H}_{2} \mathrm{O}_{2}$ also in reasonable yields.

${ }^{1} \mathrm{H} \mathrm{NMR}\left(\mathrm{CDCl}_{3}, 400 \mathrm{MHz}\right): 7.25$ (dd, 8, $\left.2 \mathrm{~Hz}, 1 \mathrm{H}\right), 7.15(\mathrm{dd}, 8,2 \mathrm{~Hz}, 1 \mathrm{H}), 6.95(\mathrm{~m}, 2 \mathrm{H}), 6.80(\mathrm{~d}, 6 \mathrm{~Hz}, 2 \mathrm{H}), 6.70$ (d, $\left.6 \mathrm{~Hz}, 1 \mathrm{H}\right)$, 5.20-5.10 (m, 1H), 4.00-3.80 (m, $2 \mathrm{H}), 3.50-3.30(\mathrm{~m}, 2 \mathrm{H}), 1.20(\mathrm{~s}, 3 \mathrm{H})$.

IR (KBr, cm $\left.{ }^{-1}\right): 3363,3450$ (br), 3058, 2969, 1659, 1613, 1597, 1499, 1470, 1387, 1253, 1147, 1093.

\section{Animal studies}

\section{Materials and Methods}

The preparation and characterization of BLNO and CLNO is described. Streptozotocin and solvents and reagents were purchased from Sigma-Aldrich and Merck (Hyderabad, India).

\section{Procurement of animals and maintenance}

Male and female Wistar rats of body weight 200-250 g were procured from Sainath Agency, Hyderabad. Animals were acclimatized for 10 days to our prior experiment, maintained at temperature of 21 to $\pm 2{ }^{\circ} \mathrm{C}$. The animals were standardized by 12 hours light and 12 hours dark schedule. Six animals were housed per cage. All the animals were quarantined for 4 days and had free access to sterile formulated feed pellets and filtered potable clean water. The study was conducted in compliance with standard animal use practices at Virchow Biotech Private Limited, Department of preclinical toxicology, Hyderabad, India (Registration No. 546/02/A/ CPSCEA, India). Animal Ethics Committee Approval dated. 4 April 2014.

\section{Experimental induction of diabetes in Wistar rats}

The rats were subjected to fasting overnight, and then diabetes condition was induced with intraperitoneal injection (i.p.) of Streptozotocin (STZ, $40 \mathrm{mg} / \mathrm{kg}$ dose). The STZ was freshly dissolved in citrate buffer $(0.01 \mathrm{M}, \mathrm{pH} 4.5)$ [19]. The injection volume was $1.0 \mathrm{~mL} / \mathrm{kg}$ [13] After 3 days of standard STZ induction, blood glucose levels were measured and the animals with a glucose concentration of more than $300 \mathrm{mg} / \mathrm{dL}$ were classified as diabetic [19] and taken for the experiment. Administration of the BLNO, CLNO was initiated on $4^{\text {th }}$ day after STZ injection and this was considered to be the $1^{\text {st }}$ day of treatment, which was continued for 28 days for $1 \mathrm{X}$ dosage and 18 days for $5 \mathrm{X}$ dosage.

\section{Effect of BLNO and CLNO in STZ induced rats}

After noting the insulinogenic activity of novel antidiabetic compounds CLNO and BLNO, we tested these N-oxides in Wistar rats. 
First the pancreas of animals were impaired by treatment with streptozotocin (STZ) at $40 \mathrm{mg} / \mathrm{kg}$ and developed antidiabetic model to screen the drug compounds. The rats were divided into 5 groups each $n=6$ :

Group 1: Positive control rats $(3 \mathrm{M}+3 \mathrm{~F})$ were administered STZ but no drug (diabetic rats)

Group 2: Male diabetic rats received BLNO at $1 \mathrm{mg} / \mathrm{kg}$ dose (intraperitoneal, i.p.)

Group 3: Male diabetic rats received CLNO at $1 \mathrm{mg} / \mathrm{kg}$ dose (i.p.)

Group 4: Female diabetic rats received BLNO at $1 \mathrm{mg} / \mathrm{kg}$ dose (i.p.)

Group 5: Female diabetic rats received CLNO at $1 \mathrm{mg} / \mathrm{kg}$ dose (i.p.)

\section{Oral glucose tolerance test (OGTT)}

Oral glucose tolerance test (OGTT) for non-diabetic female rats were performed according to the standard method [20]. In short, Group 1 to 5 animals (each group consisted of $6 \mathrm{M}+6 \mathrm{~F}$ ) were selected for OGTT test after starving for 16 hours (water only). Baseline glucose levels were measured by glucometer to the glucose fed ( $3 \mathrm{~g} / \mathrm{kg}$ body weight) rats. The standard and test compounds were administered in oral form for MHCL and SPMH and intraperitoneal for BLNO and CLNO.

Group 1 = normal control group, CTRL (no drug)

Group 2 = MHCL dose (100 mg/kg body weight)

Group 3 = SPMH dose (100 $\mathrm{mg} / \mathrm{kg}$ body weight)

Group $4=$ BLNO dose ( $5 \mathrm{mg} / \mathrm{kg}$ body weight)

Group 5 = CLNO dose ( $5 \mathrm{mg} / \mathrm{kg}$ body weight $)$

\section{Statistical analysis}

Statistical analysis was carried out on SPSS 15.0 Windows version, where matched paired t-test comparison and repeated measures of ANOVA were applied for different time points.

\section{Results and Discussion}

Blonanserin-N-oxide single crystals suitable for X-ray diffraction were obtained from DMSO: H2O (1:1 v/v) mixture. The crystal structure was solved and refined in space group Pbca with one molecule of BLN-O and two water molecules in the asymmetric unit. From the crystal structure analysis the oxidation took place at the expected position of the piperazine $\mathrm{N}$ atom of the Blonanserin with the $\mathrm{N}-\mathrm{O}$ bond length of $1.38 \AA$. The ORTEP diagram of Blonanserin $\mathrm{N}$-oxide dihydrate confirms $\mathrm{N}$-oxidation at the expected position of piperizine N-oxide (Figure 2a). The .cif file is deposited with CCDC No. 1430496 [18]. In crystal lattice, BLNO molecules are connected via water molecules hydrogen bonded in a tetramer motif in the dihydrate crystal structure (Figure $2 \mathrm{~b}$ ).

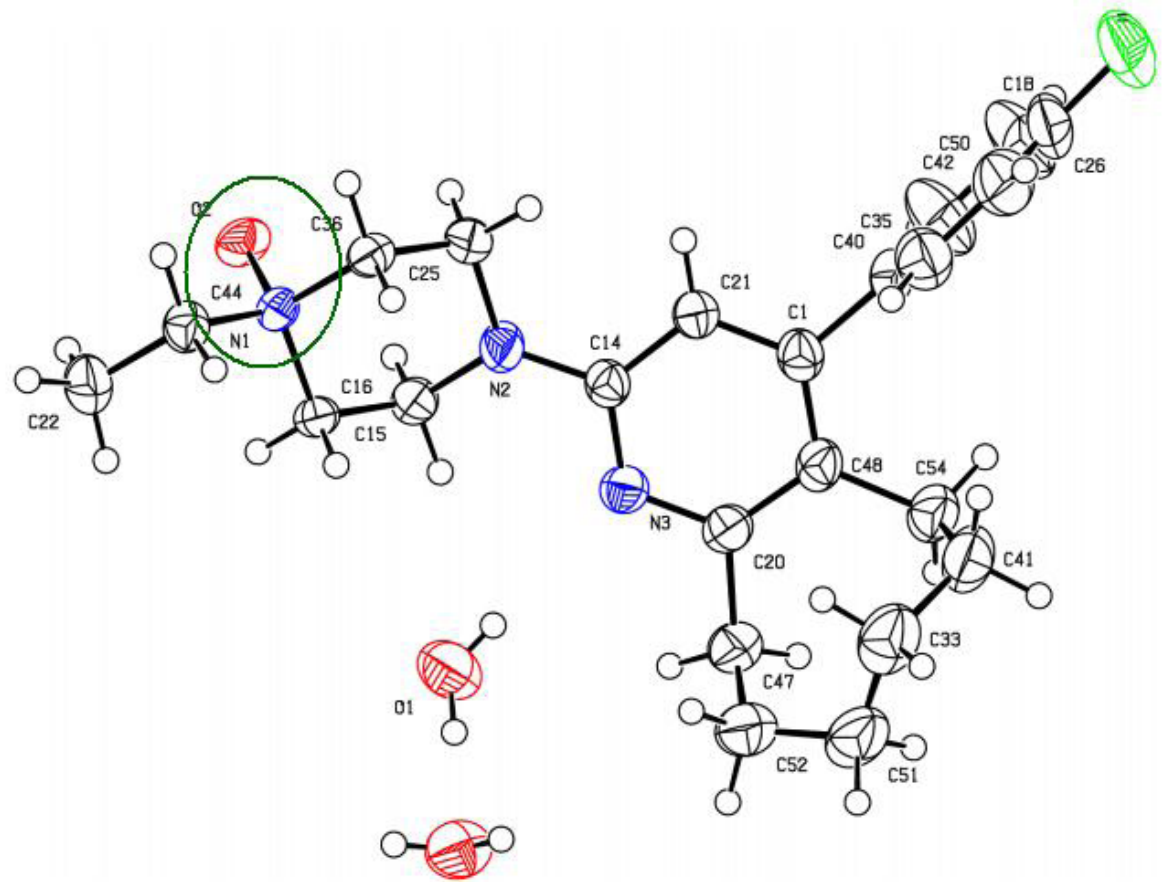

Figure 2: (a) ORTEP diagram of BLNO dihydrate at 40\% probability level of thermal ellipsoids show that the $\mathrm{N}$-oxidation has occurred at the outer $\mathrm{N}$ atom of piperazine ring, as expected from the chemical reactivity and NMR spectrum 


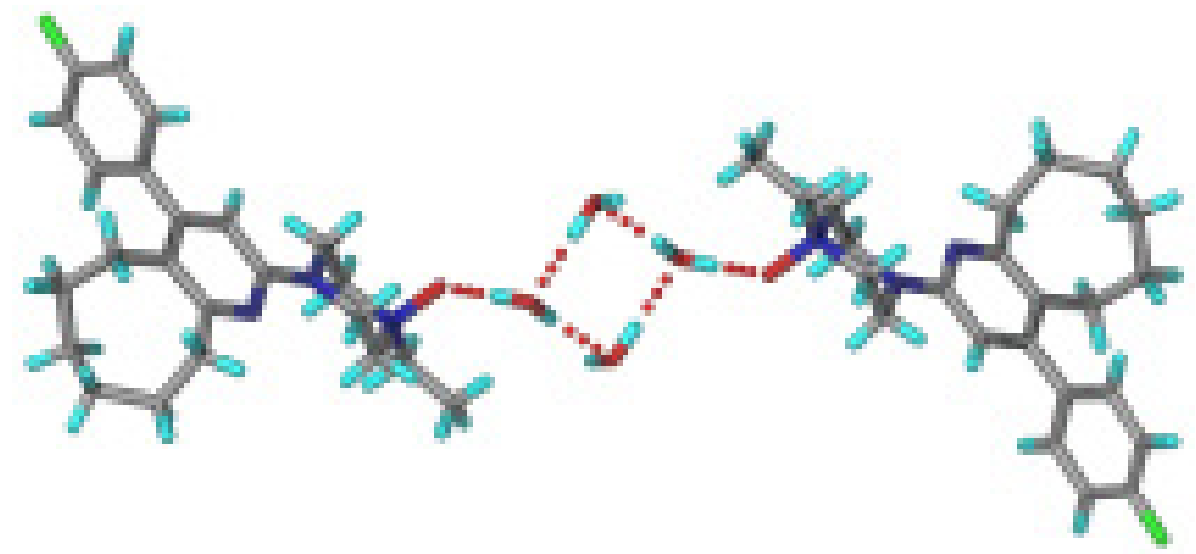

Figure 2: (b) BLNO molecules are connected via water molecules hydrogen bonded in a tetramer motif in the dihydrate crystal structure

The N-oxide drugs BLNO and CLNO were compared with known anti-diabetic drugs Metformin HCl and Sitagliptin phosphate monohydrate as positive controls. The hypoglycemic effect of BLNO in glucose-induced hyperglycaemic Wistar rats provides novel lead molecule for the control of diabetes.

\section{In vivo drug efficacy}

Blonanserin is a selective antagonist of serotonin 5-HT2A and dopamine D2 receptors [15]. It has a binding affinity for the dopamine D2 receptor that is superior to that for clozapine. Both clozapine and blonanserin acutely impair insulin sensitivity to the pancreas $[15,21]$ But the natural metabolite of clozapine (N-oxide of clozapine) studied in the treatment of Tg mice with CLNO $(1 \mathrm{mg} / \mathrm{kg}$ i.p. route) in streptozotocin induced model led to the activation of $\beta$-cell signaling pathway leading to in reduced glucose levels.. In this study, bolanserin N-oxide was treated at $1 \mathrm{mg} / \mathrm{kg}$ dosage $(\sim 1 \mathrm{mg} / \mathrm{kg}$ of BLNO) and $5 \mathrm{mg} / \mathrm{kg}$ dosage in both STZ induced model and Oral Glucose tolerance test (OGTT).

\section{$\mathrm{X}$ dose study}

Fasting blood glucose level and body weight were measured at $1 \mathrm{st}, 3^{\text {rd }}, 6^{\text {th }}, 9^{\text {th }}, 12^{\text {th }}, 15^{\text {th }}, 18^{\text {th }}, 21^{\text {st }}, 24^{\text {th }}$, and $27^{\text {th }}$ day. The pancreas of rats was impaired by STZ treatment $(40 \mathrm{mg} / \mathrm{kg}$ ) and then study was started after 3 days. Blood samples were obtained by pricking the tail vein. The N-oxides of antipyschotic drugs BLNO and CLNO showed positive results at $1 \mathrm{mg} / \mathrm{kg}$ dosage. Plasma glucose values decreased significantly $(\mathrm{P}<0.0001)$ from about $380 \mathrm{mg} / \mathrm{dL}$ to $90 \mathrm{mg} / \mathrm{dL}$ at the end of 28 days, while for the control group (labeled CTRL, no drug) the value increased to 550-600 mg/dL (Figure 3; values are listed in Table S1). The dramatic increase in glucose levels in the control group was due to their impaired pancreas by STZ. The average body weight of rats reduced by about $10 \mathrm{~g}$ during this study period, from $205 \mathrm{~g}$ to $195 \mathrm{~g}$ (Figure S1, Supporting Information).

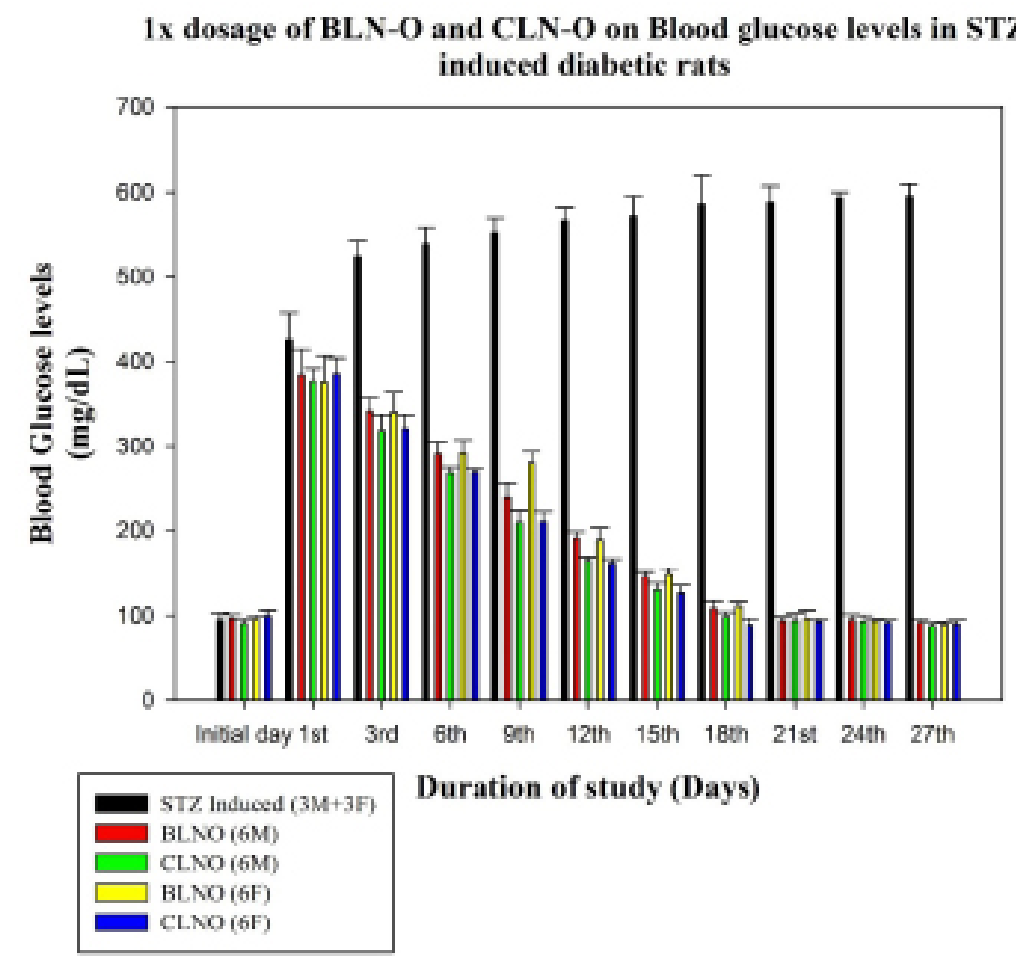

Figure 3: Glucose levels in 28 day study on STZ induced rats with drug administered daily at $1 \mathrm{mg} / \mathrm{kg}$ dose (i.p.) 


\section{$5 \mathrm{X}$ dose study}

White male and female Wistar rats of body weight of 200-250 g were taken. The animals were kept fasting overnight providing only water, after which the BLNO and CLNO drugs were administrated (i.p.) to four groups each consisting of 6 rats. If mortality was observed in 4 out of 6 animals per group, then the dose administered was assigned as a toxic dose. Body weight before and after administration were noted (Figure S2) and behavior pattern were observed and also signs of tremors, convulsions, salivation, diarrhea, lethargy, sleep and coma were seen. Treatment with $5 \mathrm{mg} / \mathrm{kg}$ of BLNO and CLNO showed significant decrease in plasma glucose values, much faster than the $1 \mathrm{X}$ dose study. Plasma glucose levels dropped significantly $(\mathrm{P}<0.0001)$ from $390 \mathrm{mg} / \mathrm{dL}$ to 90 $\mathrm{mg} / \mathrm{dL}$ at the end of $9^{\text {th }}$ day (Figure 4 and Table S2). However, no signs of toxicity or side effects were observed. BLNO and CLNO were found to be safe at dose of $5 \mathrm{mg} / \mathrm{kg}$ body weight in Wistar rats.

5X dosage of BLNO \& CLNO on Blood glucose levels in STZ induced diabetic rats

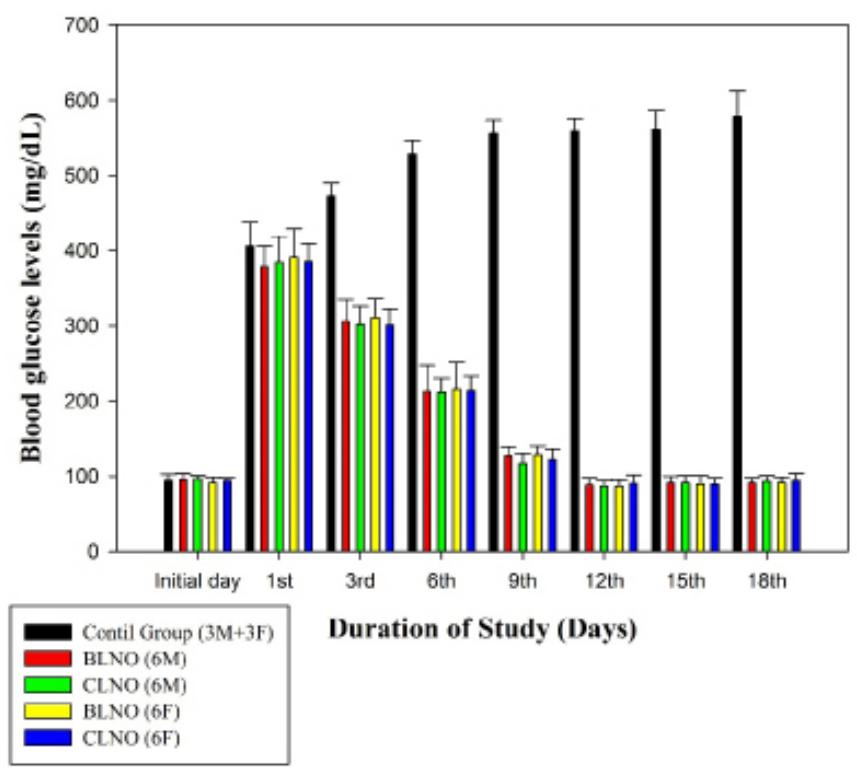

Figure 4: Glucose levels in 18 day study on STZ treated rats with drug administered daily at $5 \mathrm{mg} / \mathrm{kg}$ dose (i.p.). The control group CTRL was not treated with STZ

\section{OGTT}

Blood sample drawn from the tail vein was measured by using glucometer at 0, 15, 30, 45, 60, 90 and 120 min (Figure 5 and Table S3). Induction of hyperglycemia by intragastric ingestion of glucose resulted in a two-fold increase in plasma glucose levels (con-

Effect of BLN-O and CLN-O on oral Glucose Tolarance Test

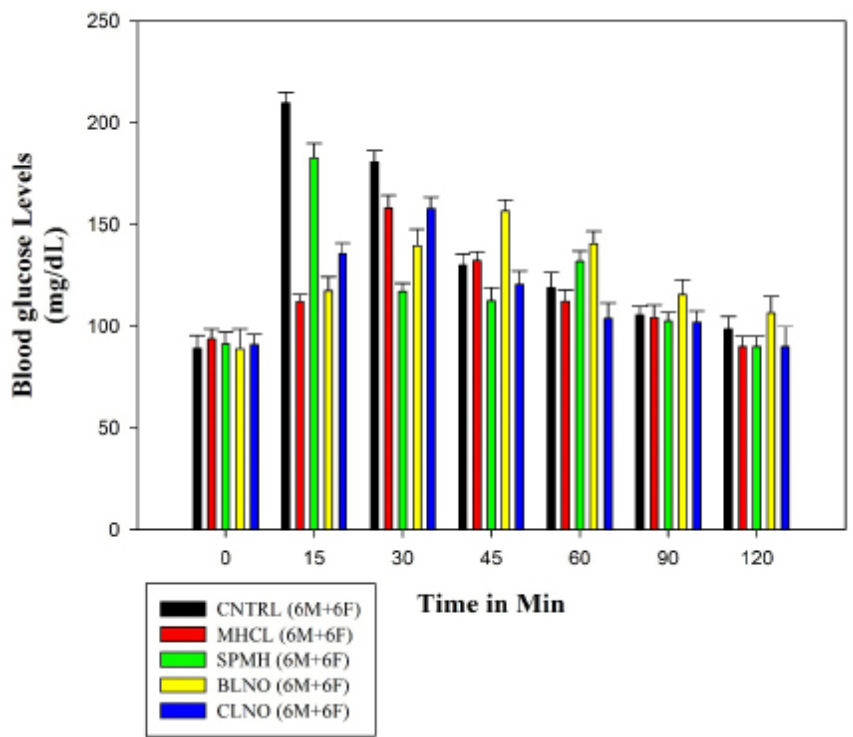

Figure 5: Comparison of test drugs CLNO and BLNO (at $5 \mathrm{mg} / \mathrm{kg}$, i.p.) with the standard drugs Metformin $\mathrm{HCl}$ and Sitagliptin phosphate monohydrate $(100 \mathrm{mg} / \mathrm{kg}$, oral) 
trol group at $15 \mathrm{~min})$ [20]. There was an immediate reduction which is significant $(\mathrm{P}<0.05)$ in glucose levels by the test drugs BLNO and CLNO, which is a very positive result because glucose levels need to be controlled after food intake. By inducing high glucose levels at the start of the experiment to almost double the normal restored glucose levels within $2 \mathrm{~h}$ to the original levels by both the test drugs BLNO and CLNO. The instant reduction in glucose levels (15-120 min) as well as those in the long term study (28 days) with the test drugs is comparable to the standard drugs.

\section{Conclusion}

To summarize, a natural metabolite of the antipsychotic drug blonanserin (BLNO) was synthesized and tested for anti-diabetic activity which is comparable to standard drugs for the treatment of type-2 diabetes. BLNO exhibited drug action to reduce and maintain lower blood glucose levels in experimental animals. The low dosage levels of $1 \mathrm{mg} / \mathrm{kg}$ and $5 \mathrm{mg} / \mathrm{kg}$ i.p. resulted in the control of sugar levels in hyperglycemic rats. This study provides a new lead for further investigation on the site specific binding and mechanism of action for Blonanserin-N-oxide. Drug repurposing [22] or the use of drugs towards one target for a different therapeutic site after minor structure modification, is providing new drug leads for pharmaceutical development.

\section{Acknowledgments}

Biotechnology Ignition Grant No. BIRAC/IKP0010/BIG-01/12 of BIRAC-DBT is acknowledged for financial assistance to Crystalin Research Pvt. Ltd., Hyderabad. We Dr. Manoj Kumar Bhat, Scientist, National Centre for Cell Science, Pune for suggestions and guidance on cell lines protocols and NCCS for providing the insulinogenic cell lines. We thank IKP Knowledge Park and University of Hyderabad for infrastructure support.

\section{Supporting Information}

\section{References}

1. Wild S, Roglic G, Green A, Sicree R, King H (2004) Global prevalence of diabetes: estimates for the year 2000 and projections for 2030. Diabetes Care 27: 1047-53. 2. Gupta R, Walunj SS, Tokala RK, Parsa KV, Singh SK, et al. (2009) Emerging drug candidates of dipeptidyl peptidase IV (DPP IV) inhibitor class for the treatment of type 2 diabetes. Current Drug Targets 10: 71-87.

3. Krentz AJ, Patel MB, Bailey CJ (2008) New drugs for type 2 diabetes mellitus: what is their place in therapy? Drugs 68: 2131-62.

4. DiStefano JK, Watanabe RM (2010) Pharmacogenetics of anti-diabetes drugs. Pharmaceuticals 3: 2610-46.

5. Deacon CF, Holst JJ (2013) Dipeptidyl peptidase-4 inhibitors for the treatment of type 2 diabetes: comparison, efficacy and safety. Expert Opinion on Pharmacotherapy14: 2047-58.

6. Weber AE, Thornberry NA (2010) Dipeptidyl peptidase 4 inhibitors. Burger's Medicinal Chemistry and Drug Discovery, Wiley.

7. Meloni AR, DeYoung MB, Lowe C, Parkes DG (2013) GLP-1 receptor activated insulin secretion from pancreatic $\beta$-cells: mechanism and glucose dependence. Diabetes Obes Metab 15: 15-27.

8. Lamont BJ, Andrikopoulos S (2014) Hope and fear for new classes of type 2 diabetes drugs: is there preclinical evidence that incretin-based therapies alter pancreatic morphology? J Endocrinol 221: T43-61.

9. Starrenburg FC, Bogers JP (2009) How can antipsychotics cause diabetes mellitus? Insights based on receptor-binding profiles, humoral factors and transporter proteins. Eu Psychiatry 24: 164-70.

10. Kahn SE, Hull RL, Utzschneider KM (2006) Mechanisms linking obesity to insulin resistance and type 2 diabetes. Nature 444: 840-6.

11. Henderson DC, Cagliero E, Gray C, Nasrallah RA, Hayden DL, et al. (2000) Clozapine, diabetes mellitus, weight gain, and lipid abnormalities: a five-year naturalistic study. Am J Psychiatry 157: 975-81.

12. Konga KC, Butchera AJ, McWilliams P, Jones D, Wess J, et al. (2010) M3-muscarinic receptor promotes insulin release via receptor phosphorylation/arrestindependent activation of protein kinase D1. Proc Natl Acad Sci USA 107: 21181-6.

13. Jain S, Ruiz DAI, Lu H, White MF, Guettier JM, et al. (2013) Chronic activation of a designer Gq-coupled receptor improves $\beta$ cell function. J Clin Invest 123: $1750-62$.

14. Guettiera JM, Gautam D, Scarselli M, Ruiz DAI, Li JH, et al. (2009) A chemical-genetic approach to study G protein regulation of $\square$ cell function in vivo. Proc Natl Acad Sci USA 106: 19197-202.

15. Deeks ED, Keating GM (2010) Blonanserin: A review of its use in the management of schizophrenia. CNS Drugs 24: 65-84.

16. Lindsley CW (2012) The Top Prescription Drugs of 2011 in the United States: Antipsychotics and Antidepressants Once Again Lead CNS Therapeutics. ACS Chem Neurosci 3: 630-1.

17. Matsuda M, Sakashita M, Yamaguchi T, Fujii T (1997) Determination of a novel anti-psychotic agent AD-5423 and its metabolites in plasma by high-performance liquid chromatography with fluorescence detection. J Pharm Biomed Anal 15: 1449-56.

18. Cambridge Crystallographic Data Center, Private deposit.

19. Manohar R, Mohammed ZS, Keerthi V, Sravani E, Srinivasulu G, et al. (2011) Hypoglycemic and hypolipidemic effects of ethanolic extract of talinum cuneifolium (wild) whole plant on streptozotocin induced diabetic rats. IJAPR 2: 184-92.

20. Islam MA, Akhtar MA, Khan MR, Hossain MS, Alam AH, et al. (2009) Oral glucose tolerance test (OGTT) in normal control and glucose induced hyperglycemic rats with Coccinia cordifolia 1 and Catharanthus roseus L. Pak J Pharm Sci 22: 402-4.

21. Ücok A, Gaebe W (2008) Side effects of atypical antipsychotics: a brief overview. World Psychiatry17: 58-62.

22. Thayer AM (2012) Drug repurposing. Chem Engg News 1: 15-25. 


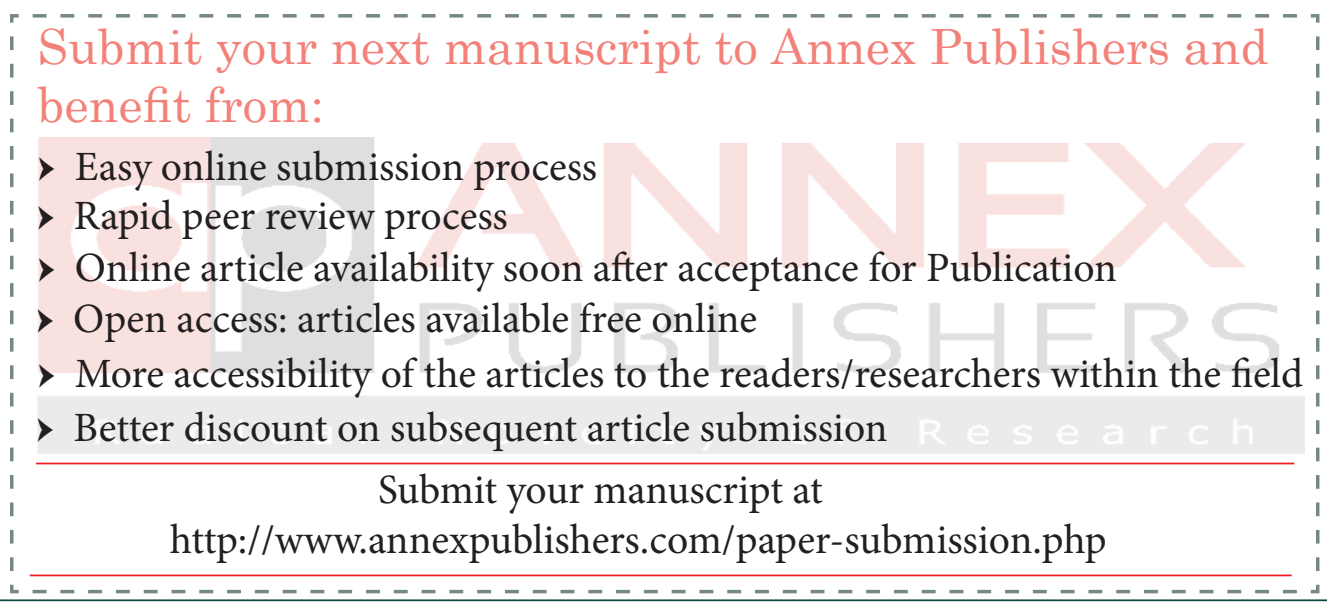

